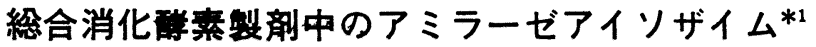

\author{
八島弘昌，植木弘明，河内一代，小川保一*2 \\ 広島県立広島病院第二研究検查科*2
}

\section{Detection of Amylase Isozymes in Commercial Multiple Digestive Enzyme Preparations*1}

\author{
Hiromasa Yashima, HiRoAKI UEKI, KazUhito KochI \\ and YASUICHI OGAWA*2 \\ Biochemistry, Hiroshima Prefectural Hiroshima Hospital*2
}

\begin{abstract}
Amylase isozymes in commercial multiple digestive enzyme preparations were detected by a discontinuous buffer system in which Tris-Borate buffer was used for supporting medium and Veronal buffer for electrophoretic chamber. The supporting medium was first immersed in Tris-Borate buffer, then electrophoresis was performed with Veronal buffer. Oxoid membrane of cellulose acetate was used, and Dy Amyl (warner-Lambert) and Blue Starch (Pharmacia) were employed as substrates. In this procedure, the isozyme bands were well separated. Quality index of 11 enzyme preparations was made up on the basis of total amylase activity determined after incubation for 2 hours at $37^{\circ}$ or $56^{\circ}$. The quality index corresponded to isozyme pattern.
\end{abstract}

総合消化酵素剤中のアミラーゼは一般に麦芽ジアスタ 一ゼ, アスペルギルス属より得られる細菌性アミラーゼ とブタ勝臟より得られる動物性アミラーゼが用いられて いる.このらちアスペルギルス属より得られるアミラー ゼは, 疁液内塩酸によって酵素活性の低下が少なく安定 な酵素として最近さかんに用いられているが，この細菌 性アミラーゼはそのアイソザイムを検討してみるとヒト のアミラーゼとは異なるものである.

市販総合消化酵素製剤は品質の比較が困難である. そ こでわれわれは総合消化酵素製剤中のアミラーゼアイン ザイムを検出し，そのザイモグラムパターンより，ヒト と同一のフミラーゼを含有するかどうかを品質の指標と して比較検討したので報告する.

\section{実酸方法}

\section{1. 試料}

\section{1) アミラーゼ標準品}

次の4種の Sigma 社製品, 寸ねわち hog pancreas (Lot No. 124C-8010), aspergillus oryzae (Lot No.

\footnotetext{
*1 本報は昭和 51 年度中国四国薬学会で発表.

*2 広島市宇品神田一丁目 5-54；5-54, Ujina-kanda 1-chome, Hiroshima-shi, 734 Japan
}

65C-0220), bacillus subtilis (Lot No. 45C-0169), diastase（局方品）を用いた。

2）市販総合消化酵素剤 (略名)

錠剂 : PZ, EZ, FS, CB, FT

カプセル剤 : JV, BZ, PT, AZ, SE, TE

\section{3）試料の調製}

市販総合消化酵素剂 1 カプセル（または錠）を $100 \mathrm{~m} \ell$ の第 2 液に溶解し， $37^{\circ}, 2$ 時間インキュベーションす る.これを沪過し，6\%丁ルブミン液で 100 倍希釉して 総アミラーゼ活性を測定した.

2. 方法

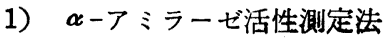

測定には DyAmyl-L 法 (日本ワーナー・ランバード 社輸入一小野菜品, 三共肘壳) を用いた。

2）アミラーゼ，アイソザイム分画法1

酢酸セルロース膜を支持体として，定電圧 $150 \mathrm{~V}, 2$ 時 間，電泳動を行い，Blue Starch (pharmacia-シオ) ギ，第一化学）を基質とした substrate agarを作製し, これに涾動した膜を密着して, $37^{\circ}$ でインキニベーショ ンしメタノールにより固定する、青色のバンドとして 現われたアミラーゼアイソザイムをデンシトメトリーに 
より测定した。

3) Substrate agar の調製

Blue Starch 1 錠 (45mg) に精製水 $1 \mathrm{ml}$ を加光溶解 後, 沸騰浴中にて溶解した $2 \%$ agar $1 \mathrm{ml}$ を加え, トレ イに流し固めた.

\section{成樍と考察}

(1) アミラーゼアイソザイムのパターン

Fig. 1 に示すようにヒト血清のアイソザイムは $2 つ$ または 3 つに分画される.この場合, 陽極側に出現する 分画を Saliva Type (S Type), 陰極側に出現する分画 を Pancreas Type (P Type) とょぶ. ヒト血清の正常 なものでは S Type, P Type はほぼ等しい。睡液およ び睡液腺のホモジネートではS Type のみが出現する.

脺液および膵蔵ホモジネートでは P Type のみが出現す る. 動物血清とその膆蔵ではブタがヒトと同様に出現す る. 麦芽より得られるジアスターゼはヒトのアイソザイ ムとほぼ同様に出現するが，細菌性アミラーゼは全く異 なる位置に出現する。

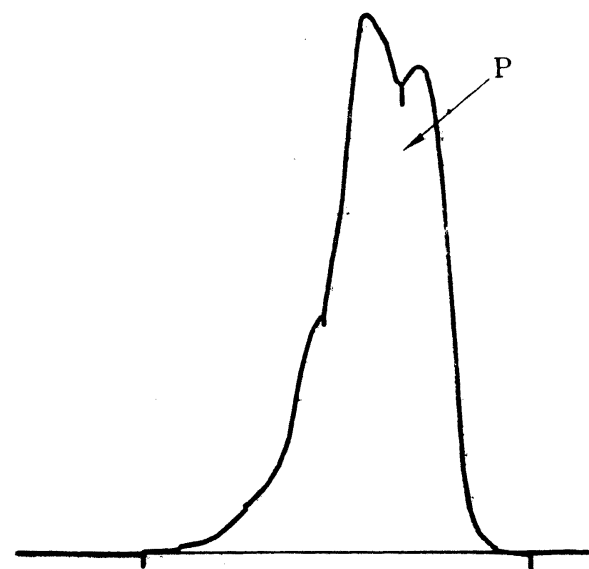

PZ Tab

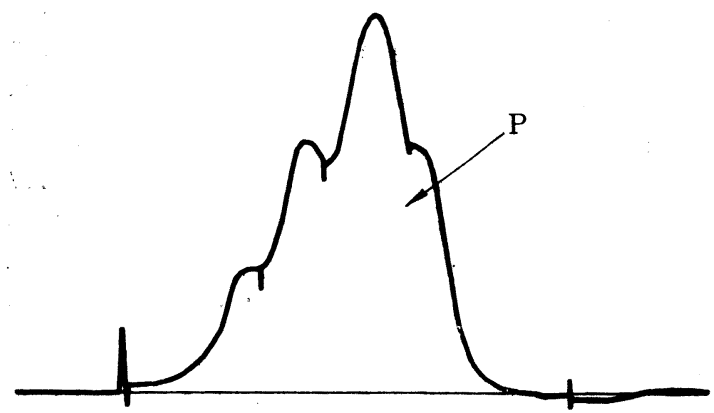

BZ Cap

Fig. 2. Densitometric Analysis of Amylase Isozyme in Digestive Enzyme Preparation

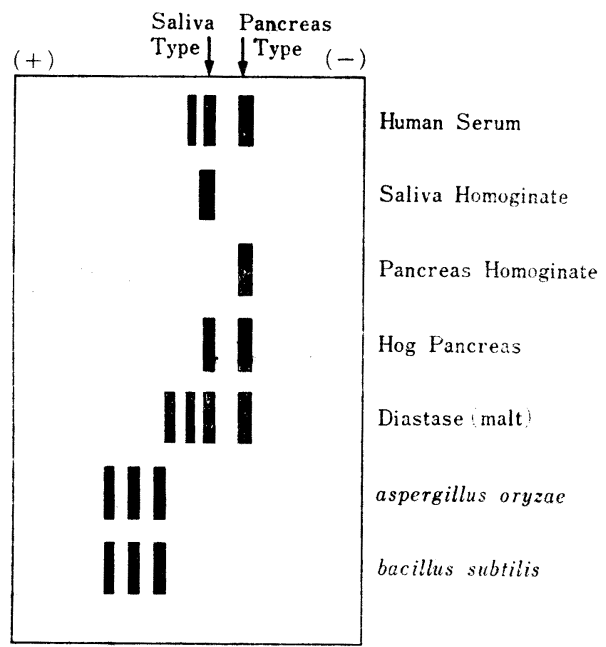

Fig. 1. Amylase Isozyme Zymogram Pattern (schematic representation)

(2)総合消化酵素剤中のアミラーゼアイソザイムパターン 総合消化酵素剤のアミラーゼ原料として は,ブタ膵臓をはじめ, 麦芽から得られ るジアスターゼ, aspergillus oryzae や bacillus subtilisなどより得られる細菌性 アミラーゼがある. Fig.2 および Fig. 3 に 各総合消化酵素剤中の, アミラーゼアイソ ザイムデンシトメトリーによるパターンを 示す. $\mathrm{PZ}$ 錠が被検 11 種中最も細菌性アミ ラービが少なく，ヒト血清と似たパターン を示した， BZ， $\mathrm{AZ}$ 各カプセルは一般的な 総合消化酵素剤のパターンである. $\mathrm{SE}$ カ プセルは最も細菌性アミラーゼの含有率が 多いハターンである.

(3)総合消化醭素剂中のアミラーゼアイソザ 么の経年変化

Fig. 4 は製造元で常温に保存された錠 剤を提供されたもので，製造後半年，1年， 2 年, 3 年を経過した FT 錠である.この 中 3 年を経過したものでは明らかに变質が 見られた. すなわら, 陰極側の P Type が 消失し，アイソザイム分画の分離が悪くな っている. 一般にブタ勝フミラーゼは不安 定で，細菌性アミラーゼは安定である。

(4)総合消化酵素剂中のアミラーゼ Quality Index

Table 1 はアミラーゼ標準品を $37^{\circ}, 2$ 時間インキュベーションと, $56^{\circ}, 2$ 時間イ 

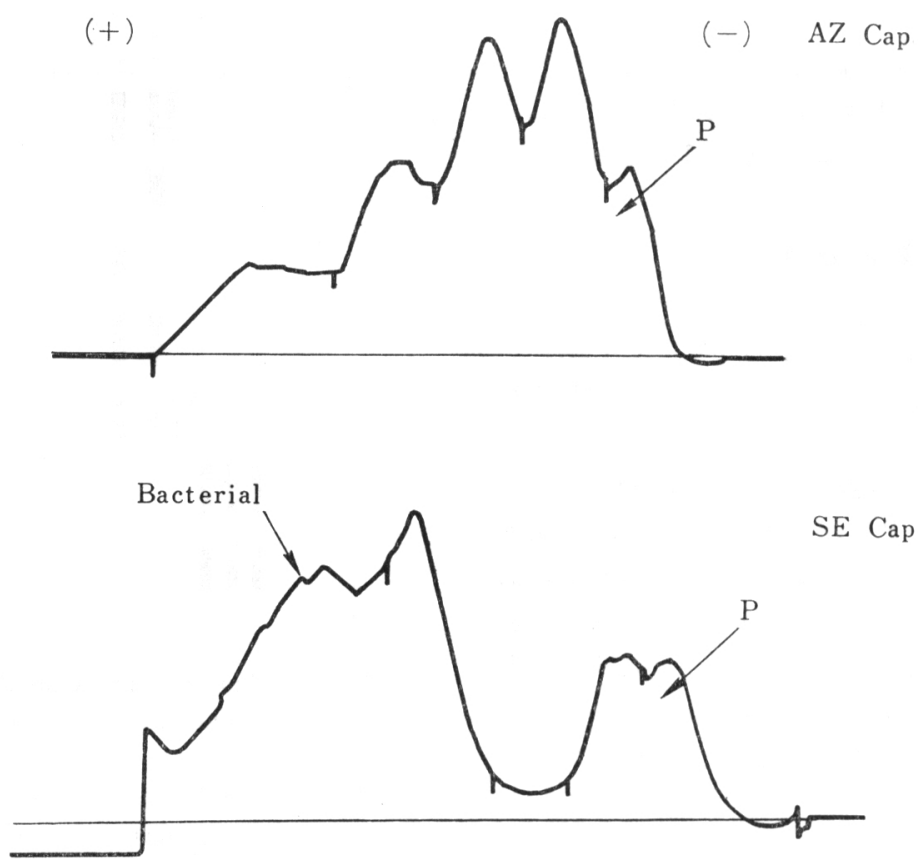

Fig. 3. Densitometric Analysis of Amylase Isozyme in Digestive Enzyme Preparation

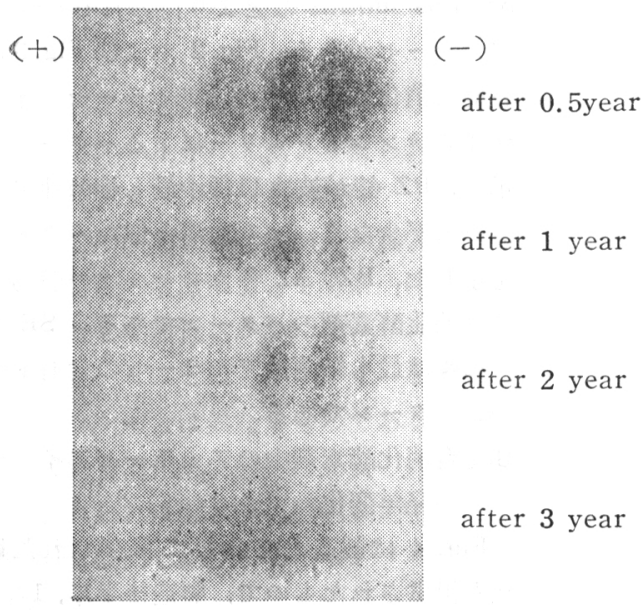

Fig. 4. Variation of Digestive Enzyme Preparation Amylase Isozyme

ンキュベーションしたものの総活性を測定し, その比を みたものである・この表によると細菌性アミラーゼはそ の比が 1 で, ほとんど変化なく, 熱に安定なことを示し ている. Table 2 は同様に総合消化酵素剤の比をみたも ので, 変化の大きいものの順に並べた. すなわち, 細菌 性アミラーゼの含有率の少い順である.これをわれわれ はQuality Index とした.この Index はアミラーゼア イソザイムパターンとほぼ一致した。
Table 1. Amylase Quality Index of Standard

\begin{tabular}{lcrc}
\hline \hline Standard & A & B & A/B \\
\hline Hog Pancreas & 23,842 u & 4,218 u & 5.65 \\
Diastase from Malt & 22,620 & 11,462 & 1.97 \\
Aspergillus oryzae & 24,290 & 23,980 & 1.01 \\
Bacillus subtilis & 23,828 & 23,780 & 1.00 \\
\hline
\end{tabular}

A: $2 \mathrm{hr}$ incubation at $37^{\circ}$

B: $2 \mathrm{hr}$ incubation at $56^{\circ}$

Table 2. Amylase Quality Index of Digestive Enzyme Preparation

\begin{tabular}{|c|c|c|c|c|c|}
\hline \multicolumn{3}{|c|}{ Sample } & \multirow{2}{*}{$\frac{A}{95,040 \mathrm{u}}$} & \multirow{2}{*}{$\frac{B}{560 \mathrm{u}}$} & \multirow{2}{*}{$\frac{A / B}{169.71}$} \\
\hline 1 & $\mathrm{PZ}$ & $\mathrm{Tab}$ & & & \\
\hline 2 & $\mathrm{EZ}$ & $"$ & 95,040 & 720 & 132.00 \\
\hline 3 & FS & " & 74,200 & 1,260 & 58.88 \\
\hline 4 & $\mathrm{CB}$ & $"$ & 148,480 & 2,880 & 51.55 \\
\hline 5 & SV & Cap & 88,480 & 2,720 & 32.53 \\
\hline 6 & Ft & $\mathrm{Tab}$ & 49,440 & 7,500 & 6.57 \\
\hline 7 & $\mathrm{BZ}$ & Cap & 82,560 & 16,640 & 4.96 \\
\hline 8 & $\mathrm{Pt}$ & " & 116,640 & 23,760 & 4.90 \\
\hline 9 & $\mathrm{AZ}$ & $"$ & 142,080 & 46,880 & 3.03 \\
\hline 10 & $\mathrm{SE}$ & " & 46,080 & 34,160 & 1.34 \\
\hline 11 & $\mathrm{TE}$ & $"$ & 47,040 & 35,840 & 1.31 \\
\hline
\end{tabular}

A: $2 \mathrm{hr}$ incubation at $37^{\circ}$

B: 2 hr incubation at $56^{\circ}$ 
結論

1. 総合消化酵素剂のアミラーゼ原料は動物性アミラー ゼとしてはブタ膵臓が用いられ，植物性アミラーゼとし ては麦芽より得られるジアスターゼと細菌性アミラーゼ が用いられているが，ヒトのアミラーゼアイソザイムと 一致するアミラーゼはブタ膵臓とジアスターゼで, 細菌 性アミラーゼはヒトのものとは異なるアミラーゼであっ た。

2. 総合消化醭素剤のアミラーゼアイソザイムを検出す ることにより，その製剂の経年変化が判明した． 常温保 存 3 年後のアミラーゼでは変質がみられた.

3. 総合消化酵素剂を $37^{\circ}$ および $56^{\circ}$ でインキュベーシ
ヨンし、そのアミラーゼ総活性を測定し, その比より Quality Index 老作製した。この Quality Index はアミ ラーゼアイソザイムと一致し, アミラーゼの含有率の指 標となり, また, 経年変化などの品質管理の指標となる ものと思われる。

\section{参考交献}

1) 八島弘昌, 植木弘明, 今井末子, 小川保一: 広島 県立病院年報, 8, (1), 257 (1976).

2) 井上良則, 大石輝雄, 橋口信彦: 薬局, 26, (12), 1495 (1975).

3）細田四郎, 吉川邦生：詮断と治療，1, 87 (1976).

4) 増田正典, 裳谷覚元他: 消化器病の臨床, 16, (1), 92 (1976).

各種抗菌性物質製剤投与時におこりやすい

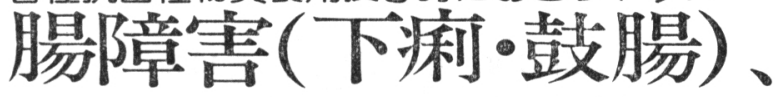

健保適用

\section{菌艾替症の治療に!}

抗菌性物質耐性乳酸菌製㓣

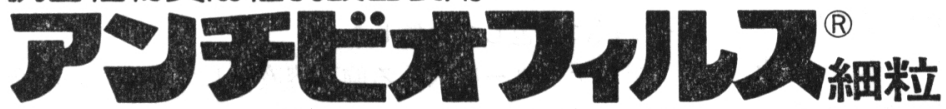

〔成分·分量〕：1 g中、ラクトバチルス・アシドフィルス生菌 $1.0 \times 10^{7} \sim 1.0 \times 10^{9}$ 個を含有する。

〔用法·用量〕：通常 1 回 $1 \mathrm{~g}$ を 1 日 3 回経口投与する。 なお、年令・症状により適宜増減する。

〔適応】：各種抗菌性物質製剤投与時におこりやすい腸障 害(下痢·鼓腸)、ならびに菌交替症の治療。

*取扱い上の注意：湿気の少ない空温に保存してください。

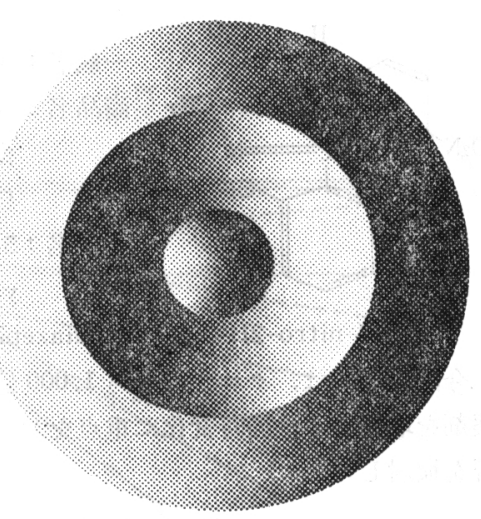

